\title{
The effect of Sc and Yb microalloying additions and aged-hardening heat treatment on corrosion behavior of Al-Mg alloys
}

\author{
N. Q. Tuan, A. C. Alves, F. Toptan, A. B. Lopes and A. M. P. Pinto
}

Sc-containing Al alloys are potentially applied in saline environment. However, the corrosion behavior and its mechanisms of Sc-containing Al alloys have not been paid much attention. In this research, the corrosion behavior of $\mathrm{Al}-4 \mathrm{Mg}$, $\mathrm{Al}-4 \mathrm{Mg}-0.3 \mathrm{Sc}$, and $\mathrm{Al}-4 \mathrm{Mg}-0.24 \mathrm{Sc}-0.06 \mathrm{Yb}$ alloys was investigated in $3.5 \mathrm{wt} \%$ $\mathrm{NaCl}$ solution by immersion and potentiodynamic polarization analysis.

Scanning electron microscope (SEM), transmission electron microscopy (TEM) and high-resolution TEM were used to characterize intermetallic phases and localized corrosion. The results showed that the Fe-containing intermetallic particles are cathodic with respect to the matrix and can lead to localized corrosion, whereas the high content of $\mathrm{Mg}$ makes the Fe-containing intermetallic particle less noble to the matrix. Yb-containing intermetallic particles did not show any dissolution of the matrix at the periphery of these particles. The results indicated that active dissolution and localized corrosion were the dominant corrosion mechanisms for Al-4Mg alloy. However the polarization curves of $\mathrm{Al}-4 \mathrm{Mg}-0.3 \mathrm{SC}$ and $\mathrm{Al}-4 \mathrm{Mg}-0.24 \mathrm{Sc}-0.06 \mathrm{Yb}$ alloys showed spontaneous passivation followed by pitting corrosion. Results suggested that age-hardening heat treatment improved the stability of the passive film on Al$4 \mathrm{Mg}-0.3 \mathrm{Sc}$ and $\mathrm{Al}-4 \mathrm{Mg}-0.24 \mathrm{Sc}-0.06 \mathrm{Yb}$ alloys.

\section{Introduction}

Al-Mg alloys are widely used in industry as non-age-hardenable, ductile, medium-strength, weldable, and corrosion-resistant materials [1]. However, these alloys have limited applications as structural materials in ship building and aerospace industry due to their relatively low strength. Alloying with small amount of scandium can substantially improve the strength of $\mathrm{Al}-\mathrm{Mg}$ alloys [2-8]. Improved strengthening, recrystallization, and weldability behavior were achieved due to the formation of a

N. Q. Tuan, A. C. Alves, F. Toptan, A. M. P. Pinto

Center MicroElectroMechanical Systems (CMEMS), Universidade do Minho, Azurém, 4800-058 Guimarães ((Portugal))

E-mail: quoctuan1884@gmail.com

F. Toptan, A. M. P. Pinto

Department of Engenharia Mecânica, Universidade do Minho, Azurém, 4800-058 Guimarães (Portugal)

A. B. Lopes

Department of Materials and Ceramic Engineering, CICECO, University of Aveiro, 3810-193 Aveiro (Portugal) high number density of elastically-hard $\mathrm{Al}_{3} \mathrm{Sc}$ ( $\mathrm{L}_{2}$ structure) precipitates which remain fully coherent with the $\alpha-\mathrm{Al}$ matrix at elevated temperatures [9-14]. The small lattice parameter mismatch of $\alpha-\mathrm{Al}$ and $\mathrm{Al}_{3} \mathrm{Sc}$ along with slow coarsening rate of $\mathrm{Al}_{3} \mathrm{Sc}$ precipitates lead to high creep resistance in Sc-containing Al alloys [9,10,12,13,15-19]. Furthermore, the thermal stability of the $\mathrm{Al}_{3} \mathrm{Sc}$ precipitates can suppress recrystallization [20-22]. However Sc-containing Al alloys are limited by cost and availability of Sc. The previous researches have demonstrated that it is possible to substitute a part of Sc with $\mathrm{Yb}$ in order to reduce the Sc content without deterioration of alloy properties [23-25].

Most of the literature has been focused on microstructure and mechanical properties while studies on corrosion behavior of Sc-containing $\mathrm{Al}$ alloys are scarce. The effect of Sc on corrosion behavior of pure Al [26,27], Al-Zn alloys [28,29], Al-Mg alloys [30-32], Al-Zn-Mg alloys [27,33-35], and Al-Cu-Li$\mathrm{Mg}-\mathrm{Ag}$ alloys [27] have been reported. The results of corrosion rates and passivation current densities indicated that the addition of Sc enhances the corrosion resistance of $\mathrm{Al}$ alloys $[26,27,30,33]$. Electrochemical investigation of coarse $\mathrm{Al}_{3} \mathrm{Sc}$ particles (diameter of $40-60 \mu \mathrm{m})$ by using a micro-capillary electrochemical cell 
method was performed by Cavanaugh et al. [36]. This study concluded that $\mathrm{Al}_{3} \mathrm{Sc}$ phase was nobler than pure $\mathrm{Al}$ in dilute chloride solutions and exhibits an extended passive behavior in the anodic range. It showed a low self-dissolution rate, and a good resistance to electrochemical breakdown. Another results for $\mathrm{Al}_{3} \mathrm{Sc}_{\mathrm{x}} \mathrm{Zr}_{1-\mathrm{x}}$ phases in $\mathrm{Al}-\mathrm{Zn}-\mathrm{Mg}-\mathrm{Cu}$ alloys were shown by Wloka et al. [35]. The authors indicated that these coarse particles disturbed the grain structure near the particle/matrix interface and initiated localized corrosion. Moreover, mass loss measurements showed that the addition of scandium increased the mass loss during the initial period. The influence of $\mathrm{Yb}$ addition and age-hardening heat treatment on corrosion behavior of $\mathrm{Al}-$ 0.28 wt\% Sc and $\mathrm{Al}-0.24 \mathrm{wt} \% \mathrm{Sc}-0.07 \mathrm{wt} \% \mathrm{Yb}$ alloys was showed in our previous study [37]. However, further studies are still needed to have a better understanding to the corrosion behaviour of Sc-containing $\mathrm{Al}$ alloys. Thus, the present work aimed to study the corrosion behavior of $\mathrm{Al}-\mathrm{Mg}, \mathrm{Al}-\mathrm{Mg}-\mathrm{Sc}$ and $\mathrm{Al}-\mathrm{Mg}-\mathrm{Sc}-\mathrm{Yb}$ alloys in $3.5 \mathrm{wt} \%$ of sodium chloride by measurement of open circuit potentials (OCPs) in constant immersion tests and by potentiodynamic polarization studies. The effect of $\mathrm{Sc}$ and $\mathrm{Yb}$ addition, intermetallic particles, and heat treatment on corrosion behavior was investigated.

\section{Experimental procedure}

The alloys of Al-4 wt\% Mg (Al-4Mg), Al-4 wt\% Mg-0.3 wt\% Sc (Al-4Mg-0.3Sc), and Al-4 wt\% Mg-0.24 wt\% Sc-0.06 wt\% Yb (Al-4Mg-0.24Sc-0.06 Yb) were cast by using commercially pure $\mathrm{Al}$ (99.83 wt\% purity), master alloys $\mathrm{Al}-20 \mathrm{wt} \% \mathrm{Mg}$ and $\mathrm{Al}-2 \mathrm{wt} \%$ $\mathrm{Sc}$ and pure $\mathrm{Yb}$ ( $99.99 \mathrm{wt} \%$ purity). Suitable masses of these starting materials were melted in a $\mathrm{SiC}$ crucible, using an electrical resistance furnace. For each alloy, pure Al was firstly melted at $800 \pm 5{ }^{\circ} \mathrm{C}$ then the master alloys were added into the melt. The melt was kept at this temperature for $30 \mathrm{~min}$ and stirred with an alumina rod to ensure homogeneity. The melt was cooled down to $720 \pm 5{ }^{\circ} \mathrm{C}$, poured into a copper mould and immediately cooled to ambient temperature by immersion in water. Cast samples were obtained in cylindrical shape having $16 \mathrm{~mm}$ diameter and $80 \mathrm{~mm}$ length. The composition of the ascast alloys was measured by X-ray spectrometer (X'Unique II, Philips) and the results are given in Table 1 . The samples of $\mathrm{Al}-4 \mathrm{Mg}-0.3 \mathrm{Sc}$ and $\mathrm{Al}-4 \mathrm{Mg}-0.24 \mathrm{Sc}-0.06 \mathrm{Yb}$ alloys were strengthened by age-hardening heat treatment at $325{ }^{\circ} \mathrm{C}$ for $5 \mathrm{~h}$ followed by water quenching.

The corrosion tests consisted in OCP and potentiodynamic polarisation measurements. Samples for each test were polished using $\mathrm{SiC}$ papers and colloidal silica suspensions down to $0.3 \mu \mathrm{m}$. A conventional three-electrode electrochemical cell, adapted from ASTM standard practice G3-89 [38], was used in both corrosion tests. A saturated calomel electrode (SCE) was used as the reference electrode, Pt electrode used as the counter electrode, and samples used as the working electrode having an exposed area of $0.07 \mathrm{~cm}^{2}$. A total $3.5 \mathrm{wt} \% \mathrm{NaCl}$ solution was used as the electrolyte. The immersion tests were performed during $96 \mathrm{~h}$ (4 days). OCP was measured just after immersion during $30 \mathrm{~min}$ and after that, for $15 \mathrm{~min}$ during the following each 4 days. The OCP and potentiodynamic polarization measurements were performed by using a Gamry Instruments Reference $600^{\mathrm{TM}}$ potentiostat controlled by the Gamry Instruments Framework $^{\mathrm{TM}}$ software (Gamry Instruments, Warminster, PA, USA). Potentiodynamic polarization measurements started from a cathodic potential of $-1.5 \mathrm{~V}$ up to the anodic domain $(0 \mathrm{~V}$ vs. SCE) with a scan rate of $0.5 \mathrm{mV} / \mathrm{s}$. Each test was repeated at least three times and the average value of corrosion potential $\left(\mathrm{E}_{\text {corr }}\right)$ and corrosion current density $\left(\mathrm{i}_{\text {corr }}\right)$ were determined by extrapolation of the Tafel lines of each polarization curve, using the software program Gamry Echem Analyst (Version 5.61). The pitting potential $\left(\mathrm{E}_{\mathrm{p}}\right)$ was extrapolated from the polarization curves.

The samples after both corrosion tests were cleaned by hot water and ultrasonic cleaner to remove the corrosion products. Microstructures of the as-cast samples, heat treated samples and corroded samples after corrosion tests were obtained by a NanoSEM-FEI Nova 200 FEG/SEM scanning electron microscope equipped with energy dispersive spectrometer (EDS) EDAX-Pegasus X4M. Transmission electron microscopy (TEM) and high resolution transmission electron microscope (HRTEM) were used to determine the structure and morphological characteristics of the precipitates in the heat treated samples. The specimens were examined by JEOL JEM-2200FS operating at $200 \mathrm{kV}$. The thin foils were prepared by double-jet electropolishing in a solution of $25 \%$ nitric acid and $75 \%$ methanol. In order to determine the average diameter of precipitates, the TEM micrographs were analyzed with Image J software. For each condition, four TEM micrographs at various positions of the sample with more than 200 precipitates were selected to measure the precipitate size.

\section{Results and discussion}

\subsection{Microstructure}

\subsubsection{Intermetallic particles}

Iron and silicon are common impurities in aluminum alloys. Intermetallic particles could be formed by alloying elements and those impurity elements play a crucial role in localized corrosion of $\mathrm{Al}$ alloys. Before exposure of samples to the $3.5 \mathrm{wt} \% \mathrm{NaCl}$ solution, their microstructure and chemical composition were

Table 1. Chemical composition of the alloys (wt\%)

\begin{tabular}{lccccccccccc}
\hline Alloy & $\mathrm{Mg}$ & $\mathrm{Sc}$ & $\mathrm{Yb}$ & $\mathrm{Si}$ & $\mathrm{Fe}$ & $\mathrm{Cu}$ & $\mathrm{Zn}$ & $\mathrm{Cr}$ & $\mathrm{Mn}$ & $\mathrm{Ti}$ & $\mathrm{Al}$ \\
\hline Al-4Mg & 3.93 & - & - & 0.128 & 0.228 & 0.024 & 0.015 & - & 0.008 & - & Bal. \\
Al-4Mg-0.3Sc & 3.86 & 0.291 & - & 0.15 & 0.325 & 0.031 & 0.018 & 0.03 & - & 0.011 & Bal. \\
Al-4Mg-0.24Sc-0.06Yb & 3.91 & 0.235 & 0.071 & 0.177 & 0.358 & 0.029 & 0.023 & 0.022 & 0.012 & 0.007 & Bal. \\
\hline
\end{tabular}


analyzed by SEM and EDS. Figure 1 shows the SEM micrographs and EDS spectra of Al-4Mg alloy. Two second phase intermetallic particles were detected: bright particles (particle marked as "Z1") with needle-like shape containing $\mathrm{Al}, \mathrm{Mg}$, $\mathrm{Si}$, and $\mathrm{Fe}$, together with Chinese script-like dark particles (particle marked as "Z2") containing $\mathrm{Mg}, \mathrm{Al}$, and $\mathrm{Si}$. Chinese script-like dark particles were observed in the grain boundaries. The SEM micrographs of $\mathrm{Al}-4 \mathrm{Mg}-0.3 \mathrm{Sc}$ and $\mathrm{Al}-4 \mathrm{Mg}-0.24 \mathrm{Sc}-0.06 \mathrm{Yb}$ alloys are shown in Figs. 2 and 3, respectively. The size of the intermetallic particles dramatically decreased to $0.5-4 \mu \mathrm{m}$ after the addition of $\mathrm{Sc}$ and $\mathrm{Yb}$ to $\mathrm{Al}-4 \mathrm{Mg}$ alloy. EDS spectra of two particles in $\mathrm{Al}-4 \mathrm{Mg}-0.3 \mathrm{Sc}$ alloy (Fig. 2) showed two types of second-phase particles: Al-Mg$\mathrm{Si}-\mathrm{Fe}$ (particle marked as "Z3") and Al-Mg-Sc-Si-Fe (particle marked as "Z4"). Al-Mg-Sc-Fe intermetallic particles were also detected in $\mathrm{Al}-4 \mathrm{Mg}-0.3 \mathrm{Sc}$ alloy. In $\mathrm{Al}-4 \mathrm{Mg}-0.24 \mathrm{Sc}-0.06 \mathrm{Yb}$ alloy, more types of intermetallic particles were detected due to the presence of $\mathrm{Yb}$, namely $\mathrm{Al}-\mathrm{Mg}-\mathrm{Sc}-\mathrm{Yb}, \mathrm{Al}-\mathrm{Mg}-\mathrm{Sc}-\mathrm{Fe}-\mathrm{Yb}$, $\mathrm{Al}-\mathrm{Mg}-\mathrm{Sc}-\mathrm{Si}-\mathrm{Fe}-\mathrm{Yb}, \quad \mathrm{Al}-\mathrm{Mg}-\mathrm{Sc}-\mathrm{Si}-\mathrm{Fe}, \quad \mathrm{Al}-\mathrm{Mg}-\mathrm{Sc}-\mathrm{Si}-\mathrm{Fe}-\mathrm{Yb}$
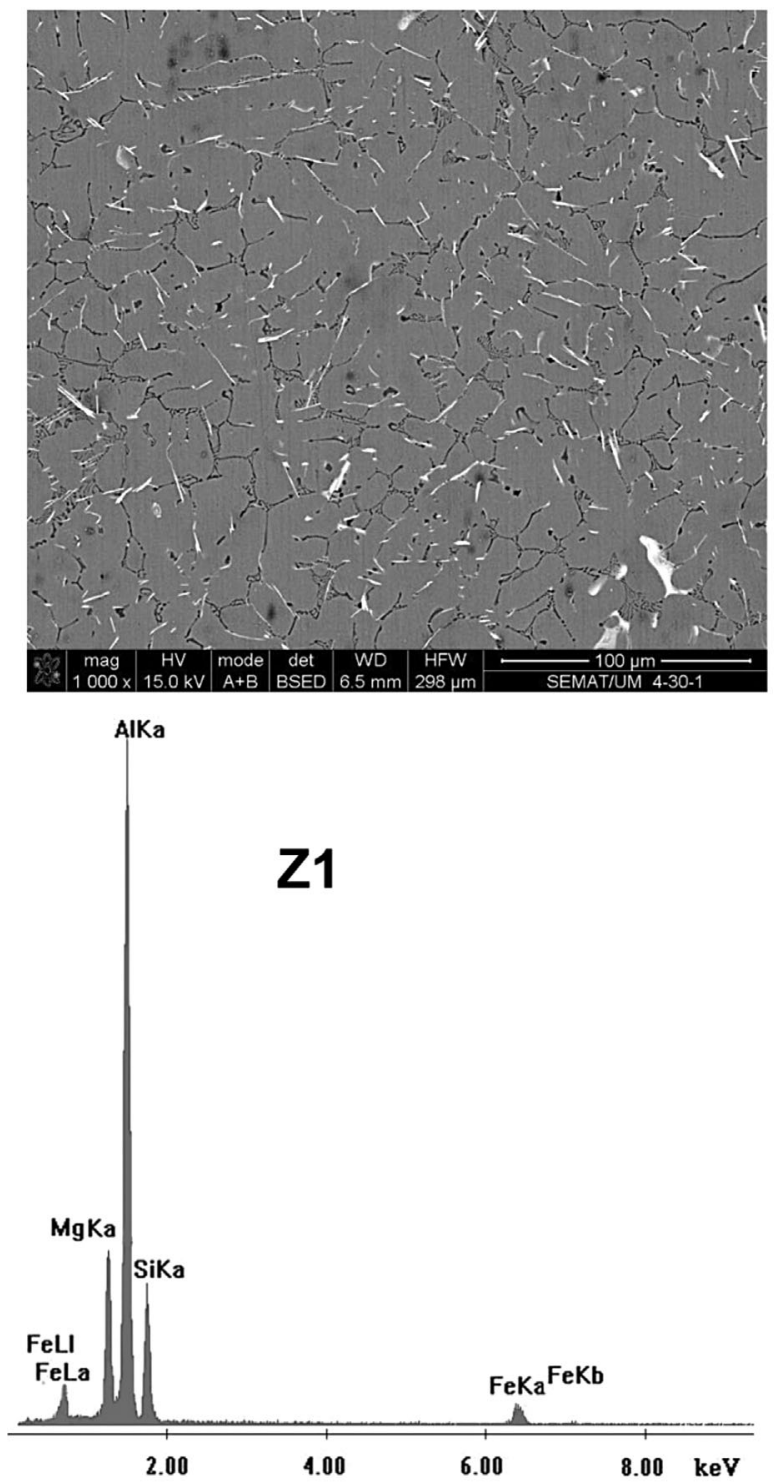

intermetallic particles. EDS spectrum of $\mathrm{Al}-\mathrm{Mg}-\mathrm{Sc}-\mathrm{Si}-\mathrm{Fe}-\mathrm{Yb}$ ("Z5" particle) was shown in Fig. 3. Chemical compositions of intermetallic particles “Z1," “Z2," “Z3," “Z4," and “Z5” were determined by EDS and the results are given in Table 2 .

These intermetallic phases were also detected on the microstructures of heat treated alloys since these phases are generally unaffected by heat treatment.

\subsubsection{Nano-precipitates in the heat treated alloys}

The precipitates forming in $\mathrm{Al}-4 \mathrm{Mg}-0.3 \mathrm{Sc}$ and $\mathrm{Al}-4 \mathrm{Mg}-0.24 \mathrm{Sc}-$ $0.06 \mathrm{Yb}$ alloys after aging at $325^{\circ} \mathrm{C}$ for $5 \mathrm{~h}$ were studied by TEM and high-resolution TEM technique. The TEM, high resolution TEM micrographs, FFT patterns, and IFFTreconstructed micrographs of $\mathrm{Al}-4 \mathrm{Mg}-0.3 \mathrm{Sc}$ and $\mathrm{Al}-4 \mathrm{Mg}-0.24 \mathrm{Sc}-0.06 \mathrm{Yb}$ alloys aged at $325{ }^{\circ} \mathrm{C}$ for $5 \mathrm{~h}$ are shown in Fig. 4. The TEM micrographs show the spheroidal $\mathrm{Al}_{3} \mathrm{Sc}$ and $\mathrm{Al}_{3}(\mathrm{Sc}, \mathrm{Yb})$ precipitates, uniformly distributed throughout the $\alpha-\mathrm{Al}$ matrix. The precipitates were fully coherent with the $\alpha-\mathrm{Al}$ matrix. There were no misfits between
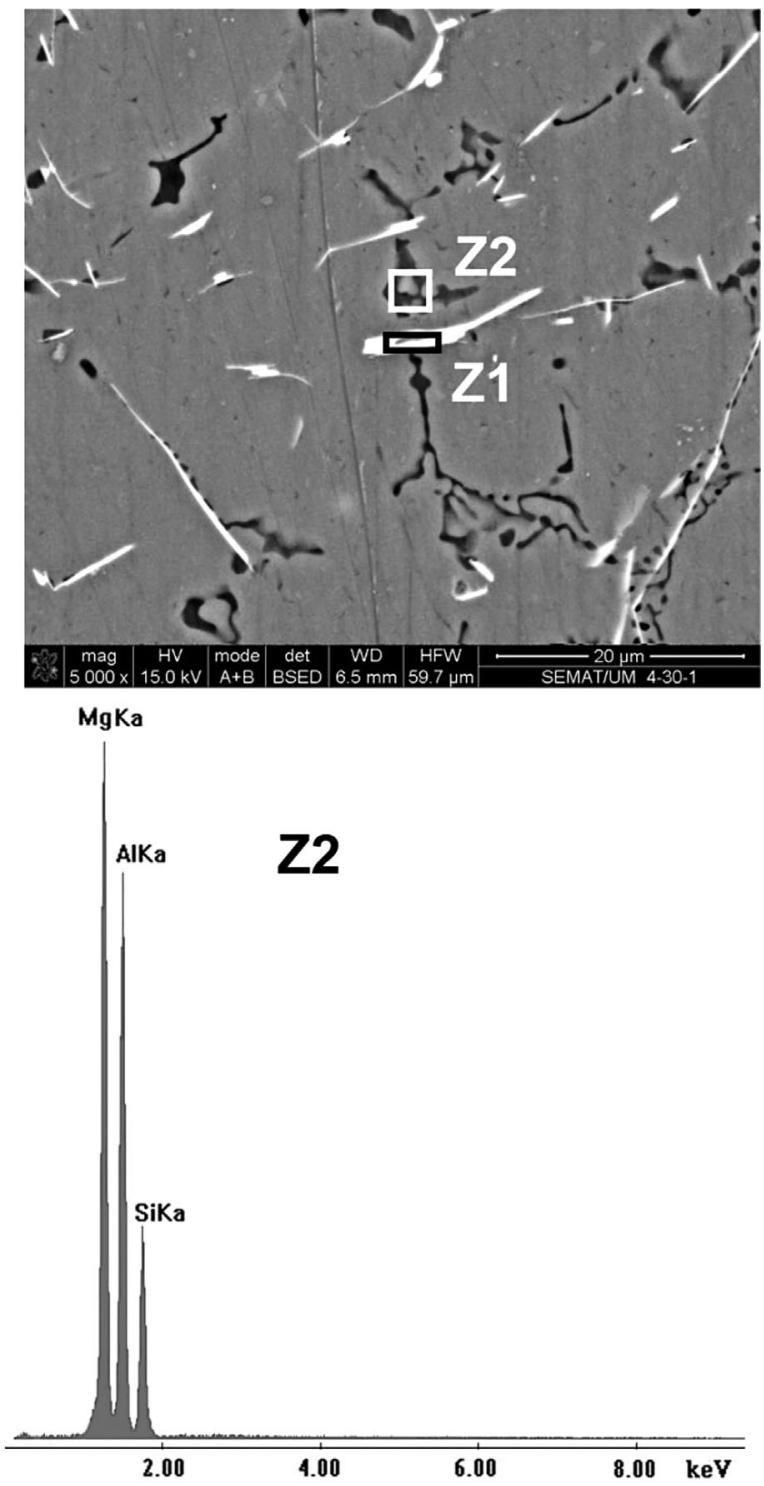

Figure 1. SEM micrographs and EDS spectra of intermetallic phases in Al-4Mg alloy. 


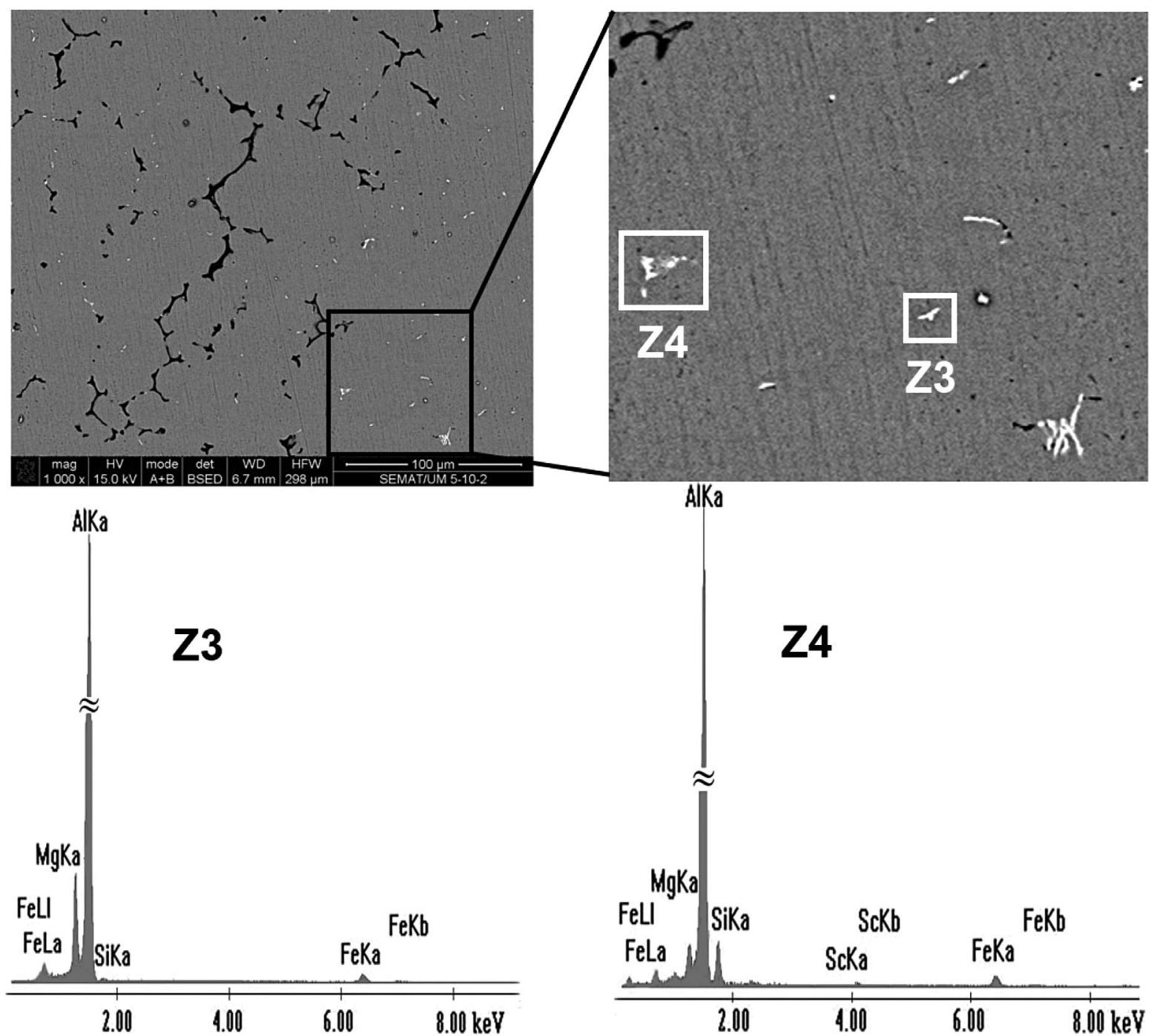

Figure 2. SEM micrographs and EDS spectra of intermetallic phases in $\mathrm{Al}-4 \mathrm{Mg}-0.3 \mathrm{Sc}$ alloy.

the precipitates and the matrix appearing in the structure. The average diameters of $\mathrm{Al}_{3} \mathrm{Sc}$ and $\mathrm{Al}_{3}(\mathrm{Sc}, \mathrm{Yb})$ precipitates in both alloys were $3.5 \pm 0.6 \mathrm{~nm}$.

According to selected area (electron) diffraction analysis, the [011] zone axis orientation was found to fit well to the simulation of the reciprocal lattice section at the orientation. The FFT pattern

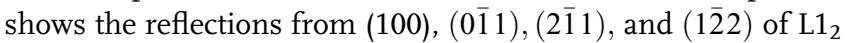
$\mathrm{Al}_{3} \mathrm{Sc}$ and $\mathrm{Al}_{3}(\mathrm{Sc}, \mathrm{Yb})$ precipitates and the reflections from (200), (3$\overline{1} 1),(1 \overline{1} 1),(2 \overline{2} 2)$, and $(0 \overline{2} 2)$ of $\alpha-A l$. The inverse fast Fourier transform (IFFT) was obtained by applying masks near reflections from (100) and could show much better contrast for precipitates identification.

\subsection{Corrosion tests}

\subsubsection{Immersion tests}

Figure 5 shows the evolution of the OCP with time for $\mathrm{Al}-4 \mathrm{Mg}$, together with $\mathrm{Al}-4 \mathrm{Mg}-0.3 \mathrm{Sc}$ and $\mathrm{Al}-4 \mathrm{Mg}-0.24 \mathrm{Sc}-0.06 \mathrm{Yb}$ as-cast and heat treated samples immersed in $3.5 \mathrm{wt} \% \mathrm{NaCl}$ solution. In the beginning period of immersion, the OCP values presented large oscillations. Over longer periods of exposure, the OCP decreased and reached relatively stable values. Decreased OCP values at the beginning of the immersion indicates corrosion whereas stabilized values may be attributed to a shift into the passive region after oxygen in the electrolyte is consumed. It was also observed that OCP values shifted to more negative values after addition of $\mathrm{Sc}$ and $\mathrm{Yb}$. However, heat treatment resulted in a positive shift as compared to the as-cast samples, that may be attributed to the presence of high number density of $\mathrm{Al}_{3} \mathrm{Sc}$ precipitates as a result of age-hardening heat treatment that increased the cathodic reactivity of the surface, thereby increased the OCP of the heat treated alloys.

Figure 6 shows representative micrographs of the corroded surfaces taken on Al-4Mg sample exposed for 4 days in $3.5 \mathrm{wt} \%$ $\mathrm{NaCl}$ solution at OCP. Chemical compositions of three selected intermetallic particles were determined by EDS and the results are given in Table 3. The particles labelled as "A1" and "A2" contain $\mathrm{Al}, \mathrm{Mg}, \mathrm{Fe}$, and $\mathrm{Si}$ whereas the particle labelled as "A3" contains $\mathrm{Al}, \mathrm{Mg}$, and $\mathrm{Si}$. It is evident to observe the dissolution of the matrix at the periphery of the $\mathrm{Al}-\mathrm{Mg}-\mathrm{Fe}-\mathrm{Si}$ intermetallic 

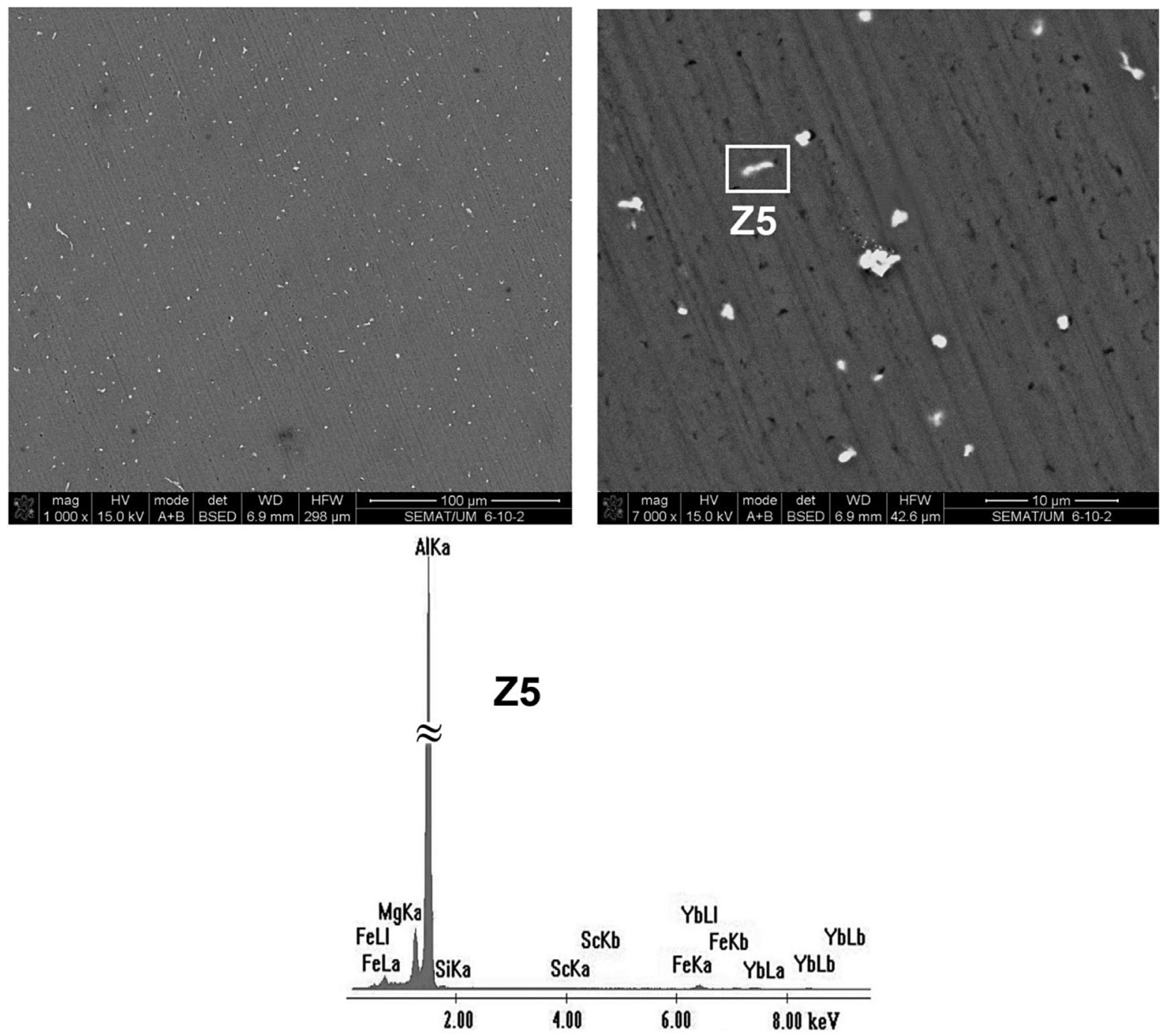

Figure 3. SEM micrographs and EDS spectra of intermetallic phases in $\mathrm{Al}-4 \mathrm{Mg}-0.24 \mathrm{SC}-0.06 \mathrm{Yb}$ alloy.

Table 2. Chemical compositions of intermetallic particles in $\mathrm{Al}-4 \mathrm{Mg}$, Al- $4 \mathrm{Mg}-0.3 \mathrm{Sc}$, and $\mathrm{Al}-4 \mathrm{Mg}-0.24 \mathrm{Sc}-0.06 \mathrm{Yb}$ alloys before immersion in $3.5 \mathrm{wt} \% \mathrm{NaCl}$ solution

\begin{tabular}{lrrrrrr}
\hline Intermetallic Particle & $\mathrm{Al}$ & $\mathrm{Mg}$ & $\mathrm{Sc}$ & $\mathrm{Yb}$ & $\mathrm{Fe}$ & $\mathrm{Si}$ \\
\hline Z1 & & & & & & \\
$\quad$ wt\% & 56.42 & 12.36 & - & - & 13.39 & 17.82 \\
$\quad$ at\% & 60.04 & 14.80 & - & - & 6.87 & 18.29 \\
Z2 & & & & & & \\
$\quad$ wt\% & 42.53 & 34.76 & - & - & - & 22.72 \\
$\quad$ at\% & 41.08 & 37.77 & - & - & - & 21.16 \\
Z3 & & & & & & \\
wt\% & 84.12 & 9.13 & - & - & 7.65 & 0.48 \\
$\quad$ at\% & 85.37 & 10.42 & - & - & 3.74 & 0.47 \\
Z4 & & & & & & \\
$\quad$ wt\% & 78.75 & 8.54 & 0.71 & - & 6.91 & 5.09 \\
at\% & 80.86 & 9.86 & 0.82 & - & 3.42 & 5.04 \\
Z5 & & & & & & \\
wt\% & 78.86 & 6.55 & 0.41 & 9.03 & 4.67 & 0.48 \\
at\% & 87.14 & 8.03 & 0.27 & 1.56 & 2.49 & 0.51 \\
\hline
\end{tabular}

particles ("A1" and "A2"). However preferential dissolution was not observed in the vicinities of the Al-Mg-Si intermetallic particles (“A3”).

Birbilis and Buchheit [39] reported a survey of corrosion potentials and electrochemical characteristics for intermetallic particles commonly present in high-strength aluminum-based alloys. Corrosion potentials of $\mathrm{Mg}$-containing intermetallic phases are between corrosion potentials of pure $\mathrm{Al}(-823 \mathrm{mV}$ vs. SCE in $0.1 \mathrm{M} \mathrm{NaCl}$ solution) and pure $\mathrm{Mg}(-1586 \mathrm{mV}$ vs. SCE in $0.1 \mathrm{M} \mathrm{NaCl}$ solution). According to Birbilis and Buchheit, corrosion potentials of Mg-containing intermetallic phases are more negative than $\mathrm{Al}$ matrix and other intermetallic phases. Therefore, these phases are active to the matrix and can act as anode leading to dissolution or $\mathrm{Mg}$ dealloying when exposed in $\mathrm{NaCl}$ solution. This mechanism has also been confirmed by some previous researches [40-42]. Different Mg-containing intermetallic phases exhibited different phenomena due to the different dissolution rates and the presence of noble elements. Mg-containing intermetallic phases with high self-dissolution rates lead to an anodic dissolution at high rates. Local alkalization 
(a)
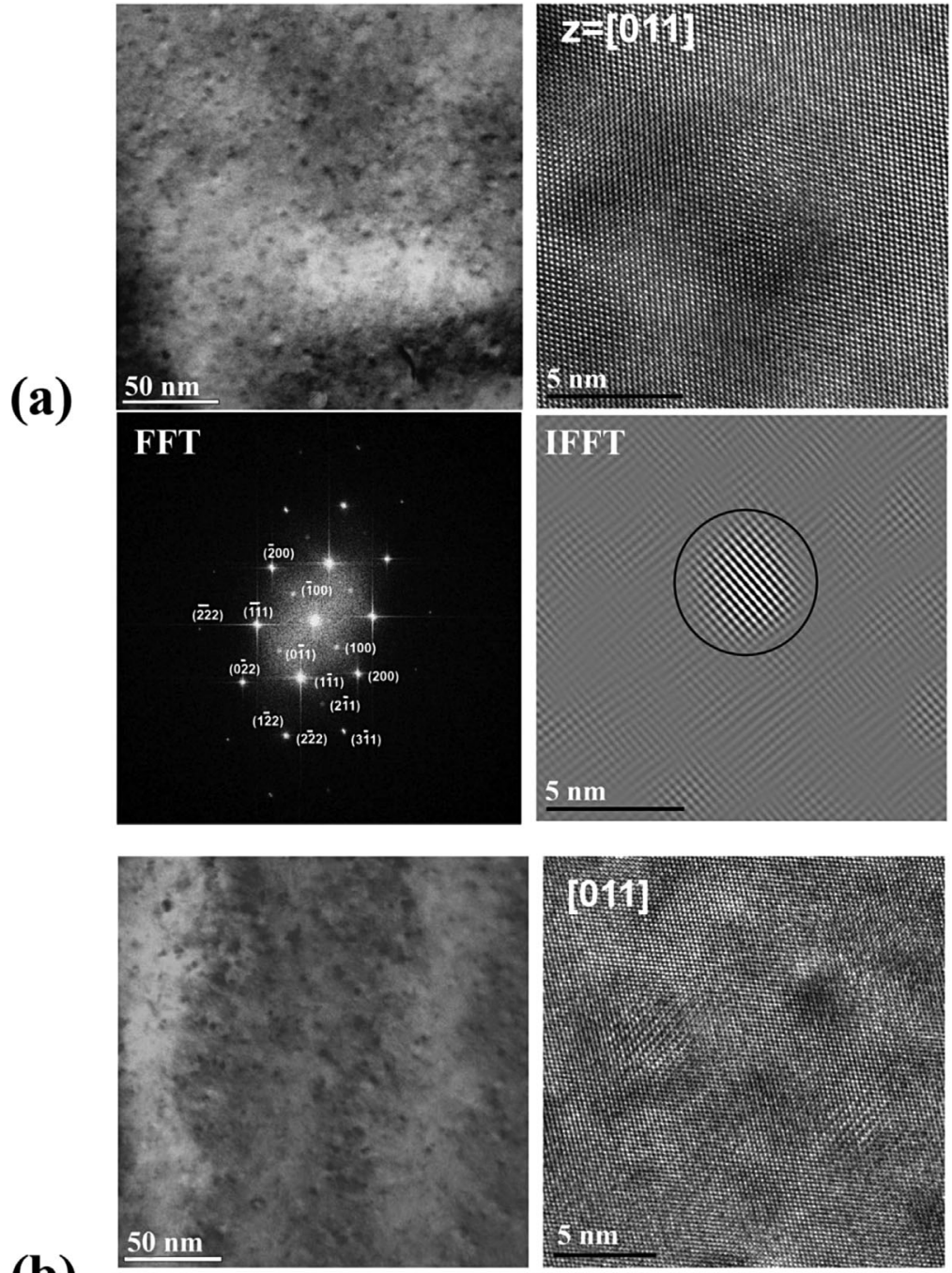

(b)
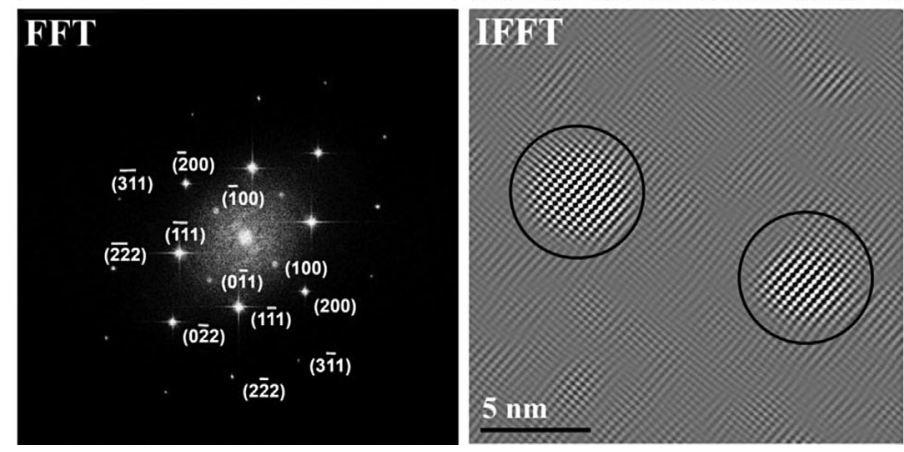

Figure 4. TEM, high resolution TEM micrograph, FFT pattern, and IFFT reconstructed micrograph of $\mathrm{Al}-4 \mathrm{Mg}-0.3 \mathrm{Sc}(\mathrm{a})$ and $\mathrm{Al}-4 \mathrm{Mg}-0.24 \mathrm{Sc}-0.06 \mathrm{Yb}$ (b) alloys aged at $325{ }^{\circ} \mathrm{C}$ for $5 \mathrm{~h}$.

appears and can dissolve the $\mathrm{Al}$ matrix in the vicinity of intermetallic particles [42]. In the Mg-containing intermetallic particle with a noble elemental component (such as $\mathrm{Al}_{2} \mathrm{CuMg}$ ), $\mathrm{Mg}$, and Al selectively dissolve and the dealloyed particle remnant is nobler than the matrix. The particle remnant can act as cathodes and support oxygen reduction to form hydroxyl ions, thus, a galvanic coupling between the noble particles and the surrounding matrix can be established. Furthermore, a local $\mathrm{pH}$ at these particles can increase and promote grooving of the surrounding matrix by alkaline dissolution [39,43]. As a consequence, peripheral dissolution around the particle remnant occurs.

Before immersion in $3.5 \mathrm{wt} \% \mathrm{NaCl}$ solution, $\mathrm{Mg}$ content in $\mathrm{Al}-\mathrm{Mg}-\mathrm{Fe}-\mathrm{Si}$ intermetallic particles (“Z1") and $\mathrm{Al}-\mathrm{Mg}-\mathrm{Si}$ intermetallic particles ("Z2") were 12.36 and $34.76 \mathrm{wt} \%$, respectively (Table 2). After immersion, $\mathrm{Mg}$ content in 


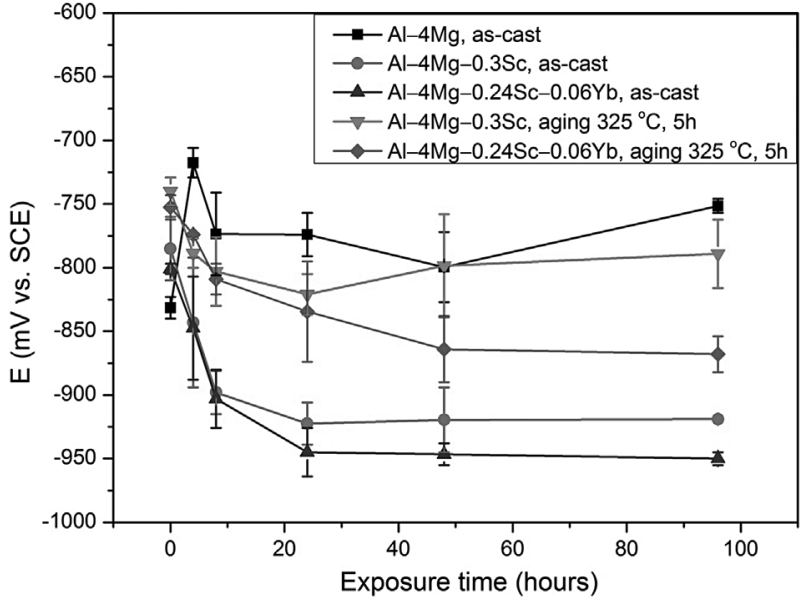

Figure 5. Evolution of OCP with time for $\mathrm{Al}-4 \mathrm{Mg}, \mathrm{Al}-4 \mathrm{Mg}-0.3 \mathrm{Sc}$, and $\mathrm{Al}-4 \mathrm{Mg}-0.24 \mathrm{Sc}-0.06 \mathrm{Yb}$ alloys (as-cast and heat treated samples).

$\mathrm{Al}-\mathrm{Mg}-\mathrm{Fe}-\mathrm{Si}$ intermetallic particles ("A1" and "A2") and $\mathrm{Al}-$ $\mathrm{Mg}-\mathrm{Si}$ intermetallic particles ("A3") were much lower with 2.76, 1.21 , and $10.11 \mathrm{wt} \%$, respectively (Table 3), indicating that $\mathrm{Mg}$ in these intermetallic particles were dissolved during immersion in $3.5 \mathrm{wt} \% \mathrm{NaCl}$ solution. The dealloyed Al-Mg-Fe-Si particle remnants containing Fe were nobler than the matrix that can lead to preferential dissolution around these particles due to the alkaline dissolution or galvanic corrosion. While, the dealloyed Al-Mg-Si particle remnants still contain high Mg content and do not contain any noble elements. These particles will not lead to any localized corrosion around them.
Table 3. Chemical compositions of intermetallic particles in $\mathrm{Al}-4 \mathrm{Mg}$ alloy after immersion in $3.5 \mathrm{wt} \% \mathrm{NaCl}$ solution for 4 days

\begin{tabular}{lccccc}
\hline Intermetallic particle & $\mathrm{Al}$ & $\mathrm{Mg}$ & $\mathrm{Fe}$ & $\mathrm{Si}$ & $\mathrm{O}$ \\
\hline A1 & & & & & \\
$\quad$ wt\% & 61.04 & 2.76 & 6.44 & 17.72 & 12.04 \\
$\quad$ at\% & 58.39 & 2.93 & 2.98 & 16.28 & 19.42 \\
A2 & & & & & \\
wt\% & 59.28 & 1.21 & 16.17 & 12.84 & 10.50 \\
at\% & 60.19 & 1.37 & 7.93 & 12.53 & 17.98 \\
A3 & & & & & \\
wt\% & 68.86 & 10.11 & - & 8.37 & 12.66 \\
at\% & 62.91 & 10.25 & - & 7.34 & 19.51 \\
\hline
\end{tabular}

Figure 7 shows representative SEM micrographs taken on Al$4 \mathrm{Mg}-0.3 \mathrm{Sc}$ as-cast and heat treated samples exposed for 4 days in $3.5 \mathrm{wt} \% \mathrm{NaCl}$ solution at OCP. Two intermetallic phases were detected, namely $\mathrm{Al}-\mathrm{Mg}-\mathrm{Sc}-\mathrm{Si}-\mathrm{Fe}$ containing intermetallic particles labelled as "B1," "B2," "B4," and Al-Mg-Sc-Fe containing intermetallic particle labelled as "B3." Both phases were $\mathrm{Fe}-$ containing intermetallic phases. The $\mathrm{Al}-\mathrm{Mg}-\mathrm{Fe}-\mathrm{Si}$ containing intermetallic phase was not detected on this group of samples. Chemical compositions of these intermetallic particles were determined by EDS and the results are listed in Table 4. It can be observed that the matrix dissolved heavily in the vicinity of the particles "B1" and "B2." A slight anodic dissolution of the matrix at the periphery of the particle "B3" was observed, whereas no preferential dissolution of the matrix was detected around the particle "B4." Table 4 shows that the Mg content in

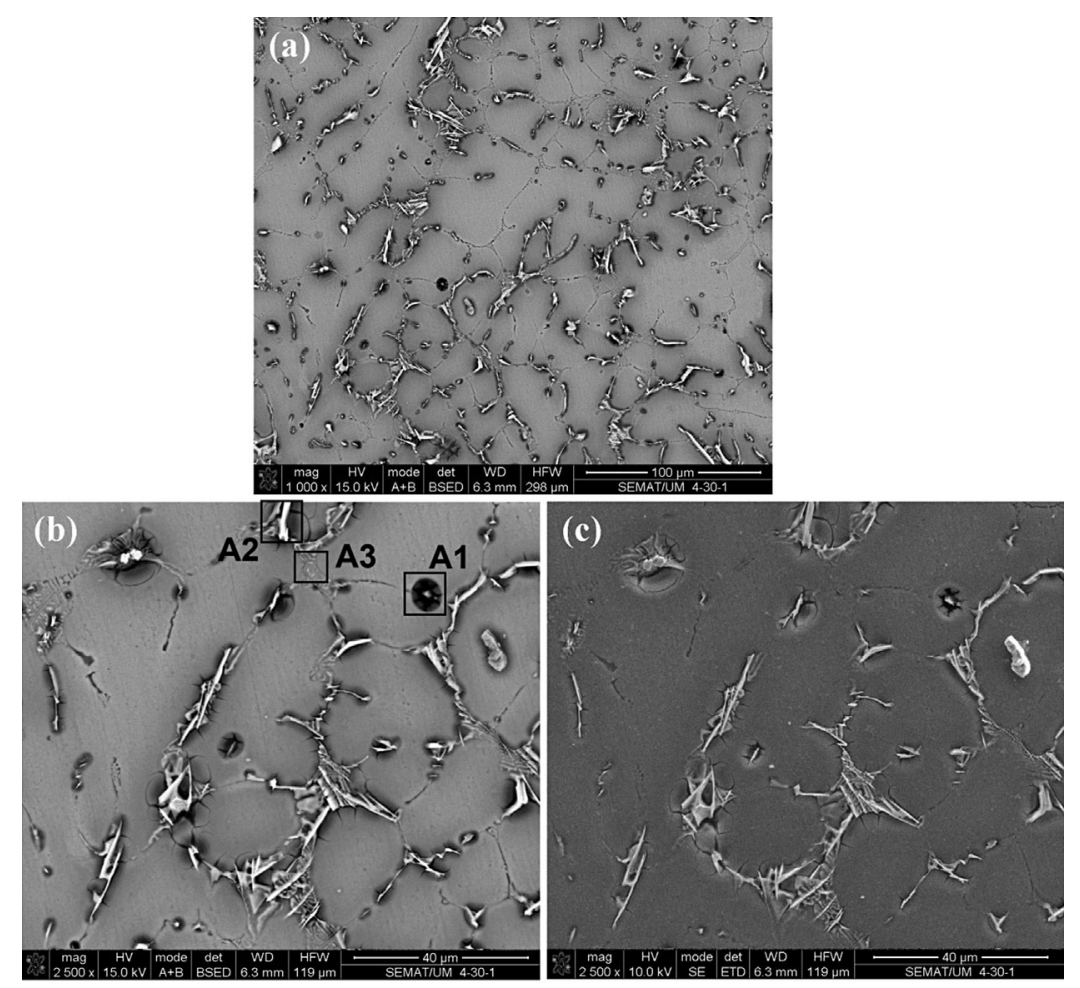

Figure 6. SEM micrographs of Al-4Mg alloy after immersion in $3.5 \mathrm{wt} \% \mathrm{NaCl}$ solution for 4 days: (a-b) BSE images and (c) SE image. 

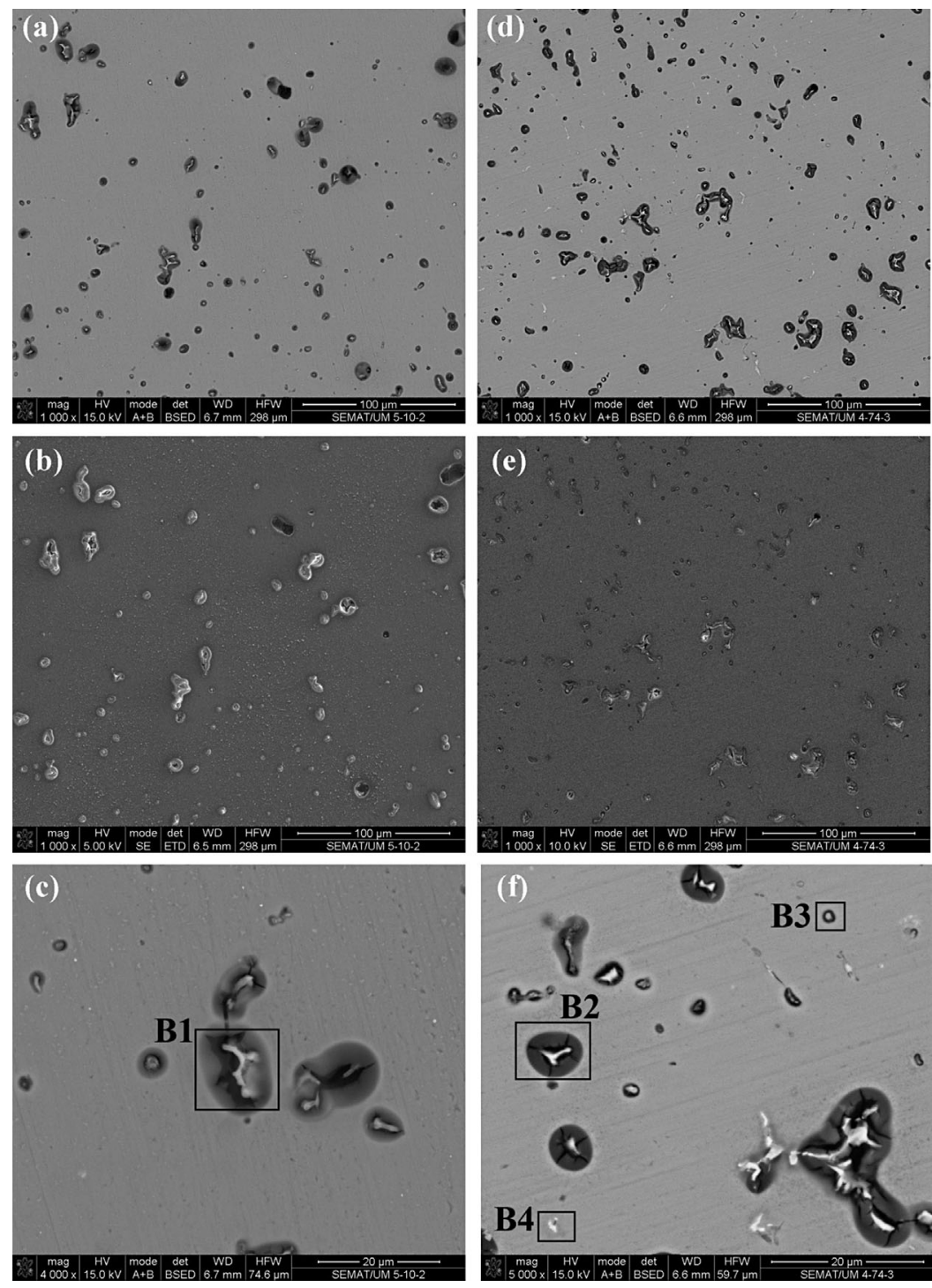

Figure 7. SEM micrographs of $\mathrm{Al}-4 \mathrm{Mg}-0.3 \mathrm{Sc}$ alloy after immersion in $3.5 \mathrm{wt} \% \mathrm{NaCl}$ solution for 4 days: (a-c) as-cast samples; (d-f) heat treated samples; (a, c, d, f) BSE images; and (b and e) SE image.

Table 4. Chemical compositions of intermetallic particles in Al-4Mg-0.3Sc alloy after immersion in $3.5 \mathrm{wt} \% \mathrm{NaCl}$ solution for 4 days

\begin{tabular}{|c|c|c|c|c|c|c|}
\hline Intermetallic particle & $\mathrm{Al}$ & $\mathrm{Mg}$ & $\mathrm{Sc}$ & $\mathrm{Fe}$ & $\mathrm{Si}$ & $\mathrm{O}$ \\
\hline \multicolumn{7}{|l|}{ B1 } \\
\hline wt $\%$ & 42.1 & 2.73 & 0.95 & 17.32 & 1.35 & 35.54 \\
\hline at $\%$ & 36.52 & 2.62 & 0.49 & 7.26 & 1.12 & 51.99 \\
\hline \multicolumn{7}{|l|}{$\mathrm{B} 2$} \\
\hline wt $\%$ & 58.17 & 1.72 & 0.83 & 14.12 & 1.11 & 24.04 \\
\hline at $\%$ & 53.36 & 1.76 & 0.45 & 6.26 & 0.98 & 37.19 \\
\hline \multicolumn{7}{|l|}{ B3 } \\
\hline $\mathrm{wt} \%$ & 69.20 & 3.54 & 0.39 & 9.12 & - & 17.75 \\
\hline at $\%$ & 64.25 & 3.65 & 0.22 & 4.09 & - & 27.80 \\
\hline \multicolumn{7}{|l|}{ B4 } \\
\hline $\mathrm{wt} \%$ & 74.83 & 5.63 & 0.56 & 10.46 & 1.18 & 7.34 \\
\hline at $\%$ & 74.84 & 6.25 & 0.33 & 5.06 & 1.13 & 12.39 \\
\hline
\end{tabular}


these intermetallic particles increased gradually from the particles "B1" and "B2"-B3" and it was maximum in the particle "B4." The higher content of Mg makes the Fe-containing intermetallic particles less noble to the matrix. Moreover, the Fe contents in the particles "B1" and "B2" were higher than in the particles "B3" and "B4." More Fe content makes intermetallic particles nobler than the matrix. Consequently, heavy dissolution of the matrix surrounding the particles "B1" and "B2," slight dissolution surrounding the particle "B3" and no dissolution surrounding the particle "B4" were observed.

Figure 8 shows representative SEM micrographs taken on $\mathrm{Al}-4 \mathrm{Mg}-0.24 \mathrm{Sc}-0.06 \mathrm{Yb}$ as-cast and heat treated samples exposed for 4 days in $3.5 \mathrm{wt} \% \mathrm{NaCl}$ solution at OCP. Chemical compositions of the particles labelled as "C1" and "C4" (Al-Mg-Sc-Yb intermetallic phase), "C2" (Al-Mg-Sc-Yb-Fe-Si intermetallic phase), "C3" (Al-Mg-Sc-Fe-Si intermetallic phase), and "C5" (Al-Mg-Sc-Yb-Fe intermetallic phase) and the results are given in Table 5. It can be seen that the $\mathrm{Yb}$-containing intermetallic phases did not lead to corrosion in the vicinity of their particles ("C1," "C4," and "C5") or a slight dissolution of the surrounding matrix was observed ("C2"). However the high content of Fe in the particle "C3" (Al-Mg-Sc-Fe-Si intermetallic phase), together with the absence of $\mathrm{Yb}$ promoted heavily dissolution of the matrix in the vicinity of this particle. The cavities were observed in both as-cast and heat treated samples of $\mathrm{Al}-4 \mathrm{Mg}-0.24 \mathrm{Sc}-0.06 \mathrm{Yb}$ alloy due to the pulling out of the intermetallic particles after preferential dissolution.

\subsubsection{Potentiodynamic polarization behavior}

Representative potentiodynamic polarization curves of $\mathrm{Al}-4 \mathrm{Mg}$, $\mathrm{Al}-4 \mathrm{Mg}-0.3 \mathrm{Sc}$, and $\mathrm{Al}-4 \mathrm{Mg}-0.24 \mathrm{Sc}-0.06 \mathrm{Yb}$ alloys (as-cast and heat treated samples) in $3.5 \mathrm{wt} \% \mathrm{NaCl}$ solution are shown in Fig. 9 , corrosion potential $\left(\mathrm{E}_{\text {corr }}\right)$, corrosion current density $\left(\mathrm{i}_{\text {corr }}\right)$, and pitting potential $\left(\mathrm{E}_{\mathrm{p}}\right)$ values are listed in Table 6 . It can be seen that corrosion potential of $\mathrm{Al}-4 \mathrm{Mg}$ alloy was more positive than $\mathrm{Al}-4 \mathrm{Mg}-0.3 \mathrm{Sc}$ and $\mathrm{Al}-4 \mathrm{Mg}-0.24 \mathrm{Sc}-0.06 \mathrm{Yb}$ alloys (both as-cast
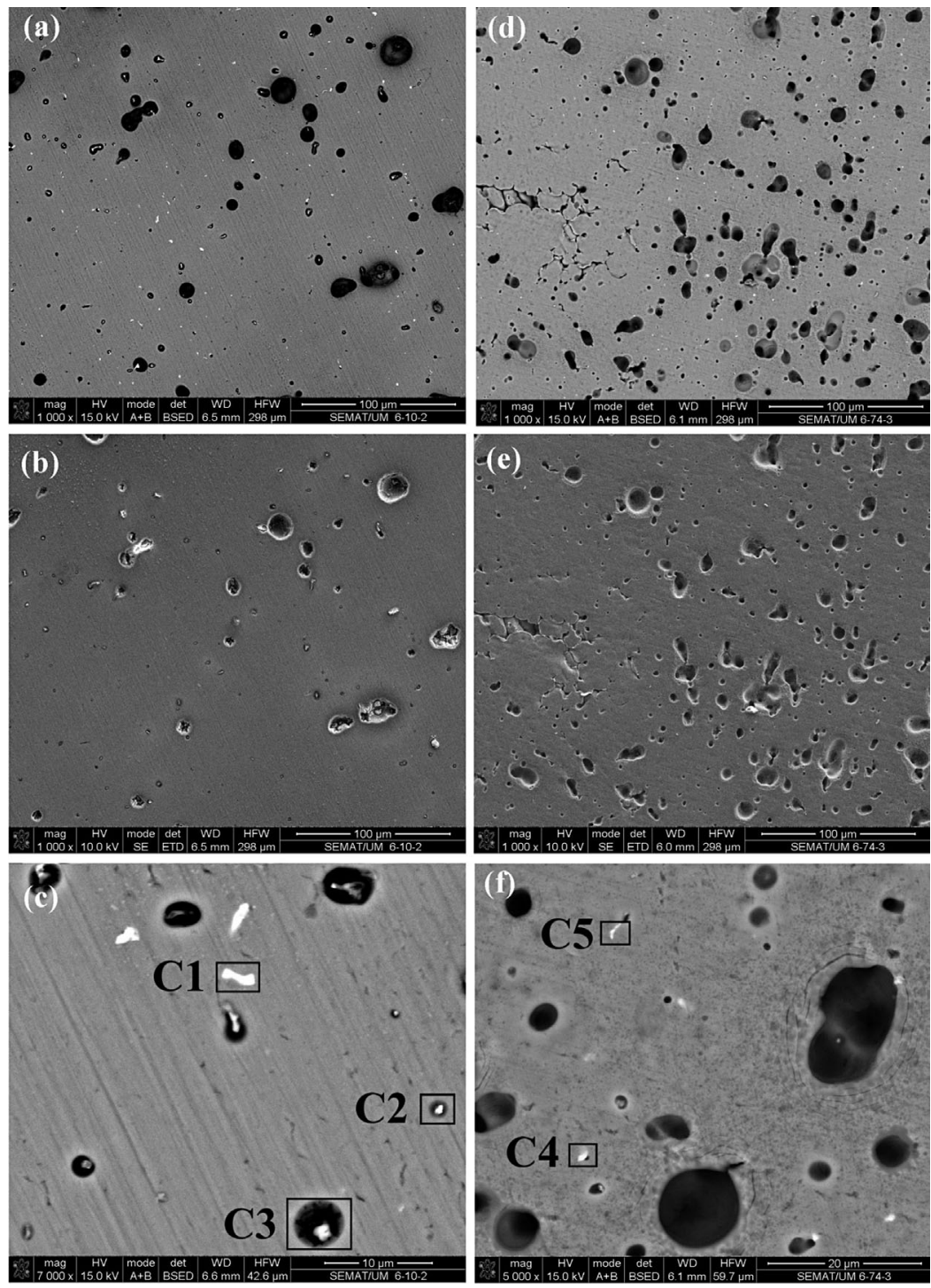

Figure 8. SEM micrographs of Al-4Mg-0.24Sc-0.06Yb alloy after immersion in $3.5 \mathrm{wt} \% \mathrm{NaCl}$ solution for 4 days: (a-c) as-cast samples; (d-f) heat treated samples; (a, c, d, f) BSE images and (b and e) SE image. 
Table 5. Chemical compositions of intermetallic particles in Al-4Mg- $0.24 \mathrm{Sc}-0.06 \mathrm{Yb}$ alloy after immersion in $3.5 \mathrm{wt} \% \mathrm{NaCl}$ solution for 4 days

\begin{tabular}{|c|c|c|c|c|c|c|c|}
\hline Intermetallic Particle & $\mathrm{Al}$ & $\mathrm{Mg}$ & $\mathrm{Sc}$ & $\mathrm{Yb}$ & $\mathrm{Fe}$ & $\mathrm{Si}$ & $\mathrm{O}$ \\
\hline \multicolumn{8}{|l|}{$\mathrm{C} 1$} \\
\hline $\mathrm{wt} \%$ & 71.77 & 14.08 & 0.41 & 10.55 & - & - & 3.19 \\
\hline at $\%$ & 75.81 & 16.51 & 0.26 & 1.74 & - & - & 5.68 \\
\hline \multicolumn{8}{|l|}{$\mathrm{C} 2$} \\
\hline $\mathrm{wt} \%$ & 74.40 & 4.08 & 0.41 & 9.04 & 1.19 & 0.38 & 10.5 \\
\hline at $\%$ & 74.98 & 4.56 & 0.25 & 1.42 & 0.58 & 0.37 & 17.84 \\
\hline \multicolumn{8}{|l|}{$\mathrm{C} 3$} \\
\hline $\mathrm{wt} \%$ & 60.85 & 4.06 & 0.53 & - & 12.16 & 0.65 & 21.76 \\
\hline at $\%$ & 55.90 & 4.14 & 0.29 & - & 5.39 & 0.57 & 33.70 \\
\hline \multicolumn{8}{|l|}{$\mathrm{C} 4$} \\
\hline wt $\%$ & 71.50 & 10.74 & 0.36 & 15.49 & - & - & 1.91 \\
\hline at $\%$ & 80.09 & 13.35 & 0.24 & 2.71 & - & - & 3.61 \\
\hline \multicolumn{8}{|l|}{$\mathrm{C} 5$} \\
\hline $\mathrm{wt} \%$ & 78.29 & 4.92 & 0.45 & 12.19 & 2.42 & - & 1.73 \\
\hline at $\%$ & 86.98 & 6.07 & 0.30 & 2.11 & 1.30 & - & 3.24 \\
\hline
\end{tabular}

and heat treated samples). The addition of $\mathrm{Sc}$ and $\mathrm{Yb}$ decreased the $\mathrm{E}_{\text {corr }}$ values in $3.5 \mathrm{wt} \% \mathrm{NaCl}$ solution, as compared to the $\mathrm{Al}-4 \mathrm{Mg}$ alloy. The heat treatment did not change the corrosion potential of $\mathrm{Al}-4 \mathrm{Mg}-0.3 \mathrm{Sc}$ and $\mathrm{Al}-4 \mathrm{Mg}-0.24 \mathrm{Sc}-0.06 \mathrm{Yb}$ alloys, significantly. It is known that Sc is electrochemically active both as in solid solution and as $\mathrm{Al}_{3} \mathrm{Sc}$ intermetallic form that can result in active dissolution on the alloys [27]. The presence of new intermetallic phases in $\mathrm{Al}-4 \mathrm{Mg}-0.3 \mathrm{Sc}$ and $\mathrm{Al}-4 \mathrm{Mg}-0.24 \mathrm{Sc}-0.06 \mathrm{Yb}$ alloys also plays an important role by decreasing the $\mathrm{E}_{\text {corr }}$ values. The cathodic current density increased significantly by the addition of $\mathrm{Sc}$ and $\mathrm{Yb}$ to $\mathrm{Al}-4 \mathrm{Mg}$ alloy, as well by the heat treatment of Al-4Mg-0.3Sc and $\mathrm{Al}-4 \mathrm{Mg}-0.24 \mathrm{Sc}-0.06 \mathrm{Yb}$ alloys, whereas, the corrosion current density was not significantly affected by the addition of $\mathrm{Sc}$ and $\mathrm{Yb}$. However, the heat treatment increased the corrosion current density of $\mathrm{Al}-4 \mathrm{Mg}-0.3 \mathrm{Sc}$ and $\mathrm{Al}-4 \mathrm{Mg}-0.24 \mathrm{Sc}-0.06 \mathrm{Yb}$ alloys. Faraday's law indicated that the electrochemical corrosion rate is proportional with the corrosion current density. Thus, the corrosion rate of $\mathrm{Al}-4 \mathrm{Mg}-0.3 \mathrm{Sc}$ and $\mathrm{Al}-4 \mathrm{Mg}-0.24 \mathrm{Sc}-0.06 \mathrm{Yb}$

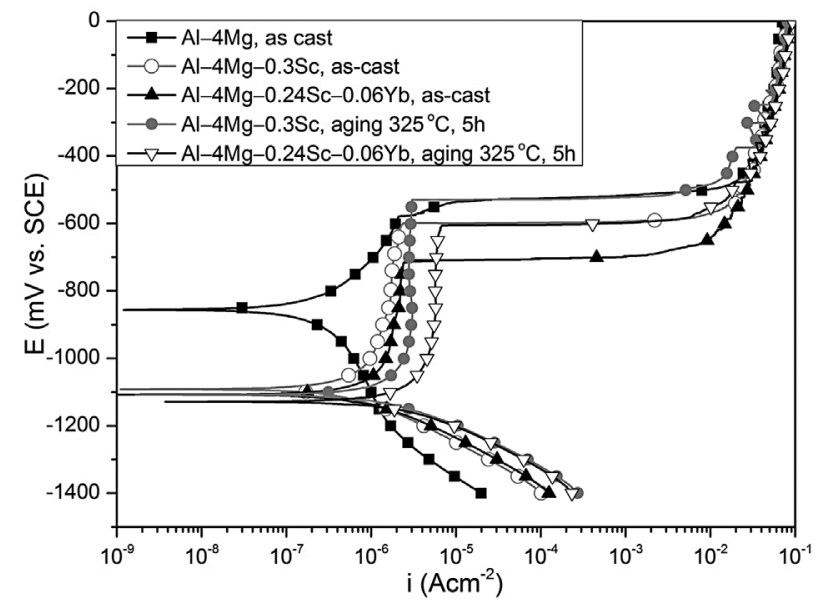

Figure 9. Representative potentiodynamic polarization curves obtained in $3.5 \mathrm{wt} \% \mathrm{NaCl}$ solution for $\mathrm{Al}-4 \mathrm{Mg}, \mathrm{Al}-4 \mathrm{Mg}-0.3 \mathrm{Sc}$, and $\mathrm{Al}-4 \mathrm{Mg}-0.24 \mathrm{Sc}-0.06 \mathrm{Yb}$ alloys (as cast and heat treated samples). alloys was increased after heat treatment. The highest corrosion current density was observed in the $\mathrm{Al}-4 \mathrm{Mg}-0.24 \mathrm{Sc}-0.06 \mathrm{Yb}$ heat treated sample. This value was in accordance with the high amount of localized corrosion that was observed in the SEM micrographs of $\mathrm{Al}-4 \mathrm{Mg}-0.24 \mathrm{Sc}-0.06 \mathrm{Yb}$ heat treated sample after immersion for 4 days in $3.5 \mathrm{wt} \% \mathrm{NaCl}$ solution (Fig. $8 \mathrm{~d}$ and e).

The polarization curve in the anodic domain of as-cast $\mathrm{Al}-4 \mathrm{Mg}$ alloy shows active corrosion followed by induced pitting where a passive plateau was not observed. Although obtained at higher current density values, the polarization curves of $\mathrm{Al}-4 \mathrm{Mg}-0.3 \mathrm{Sc}$ and $\mathrm{Al}-4 \mathrm{Mg}-0.24 \mathrm{Sc}-0.06 \mathrm{Yb}$ alloys (as-cast and heat treated samples) showed a spontaneous passivation before a distinctly breakdown by pitting corrosion. The dissolution in a neutral solution is given by Zhu and van Ooij [42]

$\mathrm{Al} \rightarrow \mathrm{Al}^{3+}+3 \mathrm{e}^{-}$

$\mathrm{Mg} \rightarrow \mathrm{Mg}^{2+}+2 \mathrm{e}^{-}$

$\mathrm{Sc} \rightarrow \mathrm{Sc}^{3+}+3 \mathrm{e}^{-}$

$\mathrm{Al}+3 \mathrm{OH}^{-} \rightarrow \mathrm{Al}(\mathrm{OH})_{3}$

$\mathrm{Sc}+3 \mathrm{OH}^{-} \rightarrow \mathrm{Sc}(\mathrm{OH})_{3}$

And the cathodic reactions are given by

$$
\begin{gathered}
2 \mathrm{H}_{2} \mathrm{O}+2 \mathrm{e}^{-} \rightarrow \mathrm{H}_{2} \uparrow+2 \mathrm{OH}^{-} \\
\mathrm{O}_{2}+2 \mathrm{H}_{2} \mathrm{O}+4 \mathrm{e}^{-} \rightarrow 4 \mathrm{OH}^{-}
\end{gathered}
$$

In $\mathrm{Al}-4 \mathrm{Mg}$ alloy, the films of bayerite and boehmite $\left(\mathrm{Al}_{2} \mathrm{O}_{3} \cdot 3 \mathrm{H}_{2} \mathrm{O}, \mathrm{Al}_{2} \mathrm{O}_{3} \cdot \mathrm{H}_{2} \mathrm{O}\right)$ can be formed but they can be 
Table 6. Summary of results of potentiodynamic polarization

\begin{tabular}{lcrr}
\hline Alloys & $\mathrm{E}_{\text {corr }}(\mathrm{mV})$ & $\mathrm{i}_{\text {corr }}\left(\mathrm{mAcm}^{-2}\right)$ & $\mathrm{E}_{\text {pit }}(\mathrm{mV})$ \\
\hline Al-4Mg, as-cast & $-851 \pm 17$ & $1.99 \pm 0.83$ & $-530 \pm 45$ \\
Al-4Mg-0.3Sc, as-cast & $-1100 \pm 33$ & $1.9 \pm 0.61$ & $-643 \pm 57$ \\
Al-4Mg-0.3Sc, aging $325{ }^{\circ} \mathrm{C}, 5 \mathrm{~h}$ & $-1110 \pm 7$ & $3.06 \pm 0.55$ & $-527 \pm 52$ \\
Al-4Mg-0.24Sc-0.06Yb, as-cast & $-1123 \pm 13$ & $1.68 \pm 0.33$ & $-670 \pm 52$ \\
Al-4Mg-0.24Sc-0.06Yb, aging $325{ }^{\circ} \mathrm{C}, 5 \mathrm{~h}$ & $-1125 \pm 9$ & $4.29 \pm 0.50$ & $-591 \pm 29$ \\
\hline
\end{tabular}

damaged with the presence of large intermetallic particles (Fig. 1). In $\mathrm{Al}-4 \mathrm{Mg}-0.3 \mathrm{Sc}$ and $\mathrm{Al}-4 \mathrm{Mg}-0.24 \mathrm{Sc}-0.06 \mathrm{Yb}$ alloys, hydrated $\mathrm{Sc}_{2} \mathrm{O}_{3}$ is accumulated to form the duplex film with bayerite and boehmite $[26,27,44,45]$. This duplex film is less defective and more stable than bayerite and boehmite films. Therefore it can enhance the passivity of $\mathrm{Al}-4 \mathrm{Mg}-0.3 \mathrm{Sc}$ and $\mathrm{Al}-4 \mathrm{Mg}-0.24 \mathrm{Sc}-0.06 \mathrm{Yb}$ alloys.

The pitting potentials of $\mathrm{Al}-4 \mathrm{Mg}, \mathrm{Al}-4 \mathrm{Mg}-0.3 \mathrm{Sc}$, and $\mathrm{Al}-4 \mathrm{Mg}-0.24 \mathrm{Sc}-0.06 \mathrm{Yb}$ as-cast samples were recorded as $-530 \pm 45,-643 \pm 57$, and $-670 \pm 52 \mathrm{mV}$ versus SCE, respectively. The values for $\mathrm{Al}-4 \mathrm{Mg}-0.3 \mathrm{Sc}$ and $\mathrm{Al}-4 \mathrm{Mg}-0.24 \mathrm{Sc}-0.06 \mathrm{Yb}$ heat treated samples were $-527 \pm 52$ and $-591 \pm 29 \mathrm{mV}$ versus $\mathrm{SCE}$, respectively. The pitting potential of $\mathrm{Al}-4 \mathrm{Mg}$ alloy decreased with the addition of Sc and continued decreasing with adding $\mathrm{Yb}$. However, the pitting potentials of Al-4Mg-0.3Sc and $\mathrm{Al}-4 \mathrm{Mg}-0.24 \mathrm{Sc}-0.06 \mathrm{Yb}$ alloys after heat treatment shifted to more positive values and were close to the value of $\mathrm{Al}-4 \mathrm{Mg}$ alloy. Thus, the addition of $\mathrm{Sc}$ and $\mathrm{Yb}$ to $\mathrm{Al}-4 \mathrm{Mg}$ tended to increase the pitting corrosion tendency, whereas heat treatment led to an improvement of the resistance to pitting corrosion of $\mathrm{Al}-4 \mathrm{Mg}-$ $0.3 \mathrm{Sc}$ and $\mathrm{Al}-4 \mathrm{Mg}-0.24 \mathrm{Sc}-0.06 \mathrm{Yb}$ alloys. After heat treatment, a high number density (as high as $10^{22} \mathrm{~m}^{-3}$ ) of nano-sized $\mathrm{Al}_{3} \mathrm{Sc}$ or $\mathrm{Al}_{3}(\mathrm{Sc}, \mathrm{Yb})$ precipitates that were fully coherent with the matrix were formed [10]. The duplex film of $\mathrm{Sc}_{2} \mathrm{O}_{3}$ reinforced $\mathrm{Al}_{2} \mathrm{O}_{3}$ is formed throughout the samples even on the precipitates sites. This passive film formed on the precipitates also coherent with the matrix. It was observed that the nanosized precipitates did not introduce any discontinuities in the passive film.

\section{Conclusions}

The corrosion behavior of $\mathrm{Al}-4 \mathrm{Mg}, \mathrm{Al}-4 \mathrm{Mg}-0.3 \mathrm{Sc}$, and $\mathrm{Al}-4 \mathrm{Mg}-$ $0.24 \mathrm{Sc}-0.06 \mathrm{Yb}$ alloys in $3.5 \mathrm{wt} \%$ of $\mathrm{NaCl}$ solution was investigated by immersion and potentiodynamic polarization analysis. Based on the results obtained from the present research, the following conclusions can be drawn

- The addition of $\mathrm{Sc}$ and $\mathrm{Yb}$ to $\mathrm{Al}-4 \mathrm{Mg}$ alloy reduced the size and changed the morphology of intermetallic particles. The Fecontaining intermetallic particles were cathodic with respect to the matrix that can result in peripheral dissolution.

- The high content of Mg made the Fe-containing intermetallic particle less noble to the matrix. Yb-containing intermetallic particles did not show any dissolution of the matrix at the periphery of these particles.
- OCP values during immersion in $3.5 \mathrm{wt} \% \mathrm{NaCl}$ shifted to more negative values for the $\mathrm{Sc}$ and $\mathrm{Yb}$ containing alloys, whereas heat treatment resulted in a positive shift. Potentiodynamic polarization curves revealed the pitting potentials of $\mathrm{Al}-4 \mathrm{Mg}$ alloy decreased after Sc and $\mathrm{Yb}$ addition, however the pitting potentials increased after heat treatment for both alloys containing $\mathrm{Sc}$ and $\mathrm{Yb}$. Nevertheless, the pitting potential values were always more positive for all samples as compared to the OCP values recorded during 4 days of immersion in $3.5 \mathrm{wt} \% \mathrm{NaCl}$ solution.

Acknowledgements: This research was supported by The Project Bridging The Gap, funded by the Erasmus Mundus External Cooperation Window Program. Acknowledgements also to the University of Minho, for the provision of research facilities.

\section{References}

[1] I. J. Polmear, in: E. Arnold (Ed.), Light Alloys: Metallurgy of the Light Metals, London, 1982.

[2] Z. Liu, Z. Li, M. Wang, Y. Weng, Mater. Sci. Eng. A 2008, 483484, 120.

[3] C. B. Fuller, A. R. Krause, D. C. Dunand, D. N. Seidman, Mater. Sci. Eng. A 2002, 338, 8.

[4] Y. A. Filatov, V. I. Yelagin, V. V. Zakharov, Mater. Sci. Eng. A 2000, 280, 97.

[5] R. Sawtell, C. Jensen, Metall. Mater. Trans. A 1990, 21, 421.

[6] G. Lapasset, Y. Girard, M. H. Campagnac, D. Boivin, Investigation of the Microstructure and Properties of a Friction Stir Welded Al-Mg-Sc Alloy, Trans Tech Publications Ltd, Zurich, Uetikon, 2003.

[7] S. Lee, A. Utsunomiya, H. Akamatsu, K. Neishi, M. Furukawa, Z. Horita, T. G. Langdon, Acta Mater. 2002, $50,553$.

[8] F. Fazeli, W. J. Poole, C. W. Sinclair, Acta Mater. 2008, 56, 1909.

[9] J. Røyset, N. Ryum, Int. Mater. Rev. 2005, 50, 19.

[10] E. A. Marquis, D. N. Seidman, Acta Mater. 2001, 49, 1909.

[11] E. A. Marquis, D. N. Seidman, D. C. Dunand, Acta Mater. 2003, 51, 285.

[12] L. S. Toropova, D. G. Eskin, M. L. Kharakterova, T. V. Dobatkina, Advanced Aluminum Alloys Containing Scandium: Structure and Properties Gordon and Breach, Amsterdam, The Netherlands, 1998.

[13] S. Iwamura, Y. Miura, Acta Mater. 2004, 52, 591.

[14] Z. Ahmad, JOM 2003, 55, 35.

[15] N. Blake, M. A. Hopkins, J. Mate. Sci. 1985, 20, 2861. 
[16] E. Clouet, A. Barbu, L. Laé, G. Martin, Acta Mater. 2005, 53, 2313.

[17] C. B. Fuller, D. N. Seidman, D. C. Dunand, Scr. Mater. 1999, 40, 691.

[18] R. W. Hyland, Metall. Mater. Trans. A 1992, 23, 1947.

[19] G. M. Novotny, A. J. Ardell, Mater. Sci. Eng. A 2001, 318, 144.

[20] L. S. Kramer, W. T. Tack, M. T. Fernandes, Adv. Mater. Process. 1997, 152, 23.

[21] M. J. Jones, F. J. Humphreys, Acta Mater. 2003, 51, 2149.

[22] V. Ocenasek, M. Slamova, Mater. Charact. 2001, 47, 157.

[23] R. A. Karnesky, M. E. van Dalen, D. C. Dunand, D. N. Seidman, Scr. Mater. 2006, 55, 437.

[24] M. E. Dalen, D. C. Dunand, D. N. Seidman, J. Mate. Sci. 2006, 41, 7814.

[25] N. Q. Tuan, A. M. P. Pinto, H. Puga, L. A. Rocha, J. Barbosa, Mater. Sci. Eng. A 2014, 601, 70.

[26] I. N. Ganiev, Prot. Met. 1995, 31543.

[27] N. V. Vyazovikina, Prot. Met. 1999, 35448.

[28] G. V. Kharina, M. V. Kuznetsov, V. P. Kochergin, Russ. J. Electrochem. 1998, 34, 482.

[29] G. V. Kharina, V. P. Kochergin, Prot. Met. 1996, 32, 134.

[30] V. S. Sinyavskii, V. D. Val'kov, E. V. Titkova, Prot. Met. 1998, $34,549$.

[31] Z. Ahmad, A. Ul-Hamid, B. J. Abdul-Aleem, Corr. Sci. 2001, 43, 1227.
[32] Z. Ahmad, Mater. Sci. Appl. 2011, 02, 244.

[33] Y. -L. Wu, C. Li, F. H. Froes, A. Alvarez, Metall. Mater. Trans. A 1999, 30, 1017.

[34] Y. Deng, Z. Yin, K. Zhao, J. Duan, J. Hu, Z. He, Corr. Sci. 2012, 65, 288.

[35] J. Wloka, S. Virtanen, Acta Mater. 2007, 55, 6666.

[36] M. K. Cavanaugh, N. Birbilis, R. G. Buchheit, F. Bovard, Scr. Mater. 2007, 56, 995.

[37] N. Q. Tuan, A. C. Alves, F. Toptan, A. B. Lopes, A. M. P. Pinto, Mater. Corr. 2015, 66, 1504.

[38] ASTM G3-89: Standard practice for conventions applicable to electrochemical measurements in corrosion testing, 1989.

[39] N. Birbilis, R. G. Buchheit, J. Electrochem. Soc. 2005, 152, B140.

[40] R. G. Buchheit, R. P. Grant, P. F. Hlava, B. McKenzie, G. L. Zender, J. Electrochem. Soc. 1997, 144, 2621.

[41] M. Shao, Y. Fu, R. Hu, C. Lin, Mater. Sci. Eng. A 2003, 344, 323.

[42] D. Zhu, W. J. van Ooij, Corr. Sci. 2003, 45, 2163.

[43] Z. Szklarska-Smialowska, Corr. Sci. 1999, 41, 1743.

[44] Z. Ahmad, B. J. A. Aleem, Mater. Corros. 2011, 62, 335.

[45] V. Neubert, B. Smola, I. Stulíková, A. Bakkar, J. Reuter, Mater. Sci. Eng. A 2007, 464, 358.

(Received: April 19, 2015)

W8404 